Vol. 8, No. 1, 2021

https://doi.org/10.23939/eem2021.01.098

UDC 353.9

JEL Classification Code: $\mathbf{H 7 3}$

N. Kalakun

Lviv Regional State Administration, Ukraine, Chief specialist

E-mail: nkalakun7@gmail.com

\title{
DECENTRALIZATION OF POWER IN EUROPEAN COUNTRIES: THE EXPERIENCE OF POLISH AND FRENCH REFORMS AS A CONCEPTUAL BASIS FOR THE ORGANIZATIONAL STRUCTURE OF UKRAINE'S GOVERNING BODIES
}

\begin{abstract}
The reform of the state power, both at the level of local self-government and at the level of the state executive authorities, cannot be carried out without reviewing the basic legislative framework, Amendments to the current legislation and the development and adoption of completely new regulations, which will be the legislative basis for the quality implementation of the public administration reform. The work analyzes the current stage of reforming the administrative and territorial structure of our state, which provides for a significant expansion of the sphere of influence and competence in certain areas of local self-government bodies. The reform of local self-government must be carried out on the basis of the Constitution and laws of Ukraine, the provisions of the European Charter of Local Self-Government and respect for the basic European principles of democracy. That is why the best example for the implementation of reforms in Ukraine can be the experience of European countries on the implementation of the reform of the new distribution of powers among the authorities. The most practical way for Ukraine will be to apply the experience of reforming the governing bodies of France and Poland. This article contains my developed comparative table of the duties of a newly established body, such as a prefect in Ukraine, as well as the corresponding duties of officials of this type in European countries (Poland and France). The work also investigated the impact of the newly established body on local self-government. The current draft of the Law of Ukraine "About Prefect" is analyzed and the appropriate conclusions are made.
\end{abstract}

Key words: decentralization, reform, local selfgovernment bodies, organizations of executive power, perfekt, powers.

\section{Introduction of the basic material}

At the current stage of Ukraine's development as a democratic legal state the important role is played by the implementation of the power decentralization reform that is based on the establishment of democratic governance, transfer of the power authority to territorial bodies, Ensuring a wide participation of citizens in the management of state affairs and society as a whole, as well as the creation of a completely new formation of bodies of executive power, which should provide adequate control over local self-government, in order to ensure their effective functioning.

The current stage of reforming the administrative and territorial structure of our state provides for a significant expansion of the sphere of influence and competence in certain areas of local self-government bodies. Namely, now the necessity of forming an integrated system of oversight and control over their activities becomes relevant. Therefore, the next stage of the decentralization reform of power is the activation of state policy in the field of creation of appropriate bodies of executive power, which will be able to ensure the level of control necessary for the effective implementation of their functions by local self-government bodies.

The responsibilities of the bodies of executive power in the system of public administration should be legally consolidated, including by amending the Constitution. The relevant oversight and 
control functions are proposed to be performed by prefects acting at the level of districts and regions.

R. Naumenko, V. Rilska, I. Bezzub, M. Pittsik, O. Sushinski and others pay attention to theoretical and practical issues of decentralization of power, development and reorganization of bodies of local self- government, as well as the reform of the governing authorities. In this area also relevant research is the current features of ensuring appropriate distribution of powers among the bodies of executive power and local self-government bodies in order to optimize their activities, Addressing the problem of unequal competence of local self-government bodies and bodies of legislative power (often, double incumbency, unreasonably large staff, exercising certain powers at an inadequate level of power, etc.)д.).

Having analyzed the practical methods and models of management reforms in the world, we can conclude that there is no one universal model that could fully ensure the successful implementation of changes and would be fully suitable for the reform of Ukraine's state management.

However, the application of administrative and territorial reforms in some European countries could be a good base model for the implementation of the last stage of the power decentralization reform in Ukraine.

The subject of the research is legislative support of the Constitutional reform on reorganization of the local level of executive power in Ukraine, in the French and Polish context, in the context of implementation of the decentralization reform process and possibility of implementation of the prefecture institution.

The subject of the research is theoretical and methodological, methodological and applied aspects of implementation of the institution of prefects in Ukraine in the European countries.

\section{Research methods}

The research was carried out using a dialectic and systematic approach to the study of economic processes. During the work, the following methods of economic research were used: the method of comparative analysis, system-structural, abstractlogical, expert evaluations, etc.
The information base of the research was the legislative and regulatory acts of Ukraine, works of domestic and foreign scientists on decentralization power reforms, in particular in the context of the example of reorganization of the administrative authorities and implementation of the institution of prefects in Poland and France for Ukraine.

\section{Specifics of the reform of the bodies of executive power}

Establishment of the institution of prefects to oversee the implementation of the Constitution and laws of Ukraine by local self-government bodies is envisaged by the draft law "On Amendments to the Constitution of Ukraine (on decentralization of power)" (No. 2217a of 01.07.2015). The powers of the prefects are described in Articles 118, 119 of the document. [1]

The amendments introduced in the draft law are fully in compliance with European and international standards, Take into account the relevant findings and observations of the Venice Commission and will be able to ensure the possibility of local self-governance and the creation of an efficient system of territorial organization of power in Ukraine. [6]

Formation of the system of interrelations between the governing bodies and local selfgovernment in a particular country for a particular locality has a number of specific features, such as the peculiarities of the legislative support, historical conditions, religious attitudes, cultural and national factors that make each model of interrelations between local and regional authorities absolutely unique even within one state.[7]

Different conditions of development, sociocultural factors, ethnic and ethnographic peculiarities are the reason why the same reforms or changes are perceived differently in different countries, Accordingly, absolutely different models of organization of local self-government and their relations with the bodies of legislative power were formed.

Even though there are different models of formation of local self-government, as well as the presence of national peculiarities in the system of division of powers between local self-government bodies and the executive power, There are common 


\section{N. Kalakun}

features that can characterize decentralization processes in European countries, which is an example for their formation in our state.

Having analyzed the experience of decentralization processes in European countries, we can identify the main characteristics of the implementation of local self-governance reforms:

- democratization through the development of local and regional autonomy - i.e., it is envisaged that not only local councils but also the future institution of the prefect will have more authority over the localities, with a view to quick interaction between the respective branches of power, without the intervention of the central authorities;

- maximum efficient resolution of local problems - a wider range of responsibilities as well as the possibility to dispose of appropriate financial resources enables to solve the first priority problems in the field, which are not critical and appropriately allocate the necessary resources for the resolution of all other issues;

- Freedom through local and regional autonomy - means a reduction in the vertical hierarchy of the presidential branch of power, and the ability to independently decide and be responsible for the development of a particular region, under the control of local and regional authorities;

- Ensuring cultural, linguistic and ethnic diversity involves maintaining a certain potential of the region, which is active in this or that locality, within the borders of one state, The main goal of the project is to ensure that the development of the region is based on the principles of the Constitution of the Russian Federation and is not a threat to the integrity of the territories and the state as a whole;

- Economic competition between the local and regional levels is equally important for the development of local and regional economies, which can be used as a guarantee for a balanced and stable development of the economy of the whole country.

Historical experience testifies to the importance of decentralization for countries which are at the stage of profound changes in the system of regulation of public relations. For countries of the transition type of economy, as our state, the decentralization reform is one of the main ways to improve the quality and quantity institutions of society and determines the potential, ways, possibilities and prospects for the development of the region, district and community. [8]

In a unitary state there is only one constitution, citizenship, the system of higher authorities. The constituent parts of the united state often have the status of administrative and territorial subdivisions. They are governed on the basis of laws adopted by central authorities and their territory can be changed by a simple state law without the consent of local authorities and the local population. Therefore, change of the formation and mechanisms of state power in the regions and districts to strengthen the role of local self-government at the same time as increasing the functions of the state power bodies on their control is legitimate, and in the conditions of decentralization process and the corresponding reforming is legitimate and logical. [9]

Comparative analysis of the responsibilities of the reformed bodies of executive power in France, Poland and the responsibilities of the future institution of the prefect in Ukraine

The main decentralization processes and power reforms in the state in the majority of European countries were completed ten years ago and were quite successful. Ukraine, however, not only lagged behind in this respect, but also went very far back, securing at the legislative level full decentralization and control over the presidential vertical. However, the current local administrations have subordinate functions - the president's representative body on the ground and the local body of the local executive power. That is why the current model of distribution of power requires reform. Analysing the experience of European countries reform, which was the best, in accordance with their power structure and the experience of which is the best to use as a model of the countries, As an example for Ukraine, the experience of France and Poland is the closest for its use in our country.

While comparing the actual duties and functions performed by the French prefect and the 
Decentralization of power in european countries: theexperience of polish and french...

Polish military leader in these countries and those that Ukrainian prefects are expected to perform, I developed a comparative table, which served as a basis for further analysis.

\section{Comparative table of responsibilities of the Ukrainian prefect of the Polish military hierarchy and the French prefect}

\begin{tabular}{|c|c|c|c|}
\hline $\begin{array}{l}\text { Organizing } \\
\text { Vladi }\end{array}$ & Ukrainian Prefect & Polish Wojewoda & French Prefect \\
\hline 1 & 2 & 3 & 4 \\
\hline $\begin{array}{l}\text { Characteristics } \\
\text { of activities }\end{array}$ & $\begin{array}{l}\text { Public servant appointed by the } \\
\text { President of Ukraine by the } \\
\text { Cabinet of Ministers of Ukraine }\end{array}$ & $\begin{array}{l}\text { The representative of the } \\
\text { Council of Ministers, who is } \\
\text { appointed and dismissed by } \\
\text { the head of the Council of } \\
\text { Ministers, upon the } \\
\text { submission of the minister, } \\
\text { whose competence includes } \\
\text { the public administration }\end{array}$ & $\begin{array}{l}\text { The representative of the } \\
\text { State in the department, } \\
\text { which is appointed by } \\
\text { Presidential Decree, } \\
\text { approved at the meeting of } \\
\text { the Government. } \\
\text { Candidates for the position } \\
\text { shall be nominated by the } \\
\text { Prime Minister and the } \\
\text { Minister of Internal Affairs }\end{array}$ \\
\hline $\begin{array}{l}\text { Powers on the } \\
\text { ground }\end{array}$ & $\begin{array}{l}\quad \bullet \text { Supervision of } \\
\text { compliance with the } \\
\text { Constitution and laws of } \\
\text { Ukraine by local self- } \\
\text { government bodies; } \\
\qquad \text { Coordinating the } \\
\text { activities of the territorial bodies } \\
\text { of the central administrative } \\
\text { authorities and supervising their } \\
\text { compliance with the legislation; } \\
\quad \text { Ensuring the } \\
\text { implementation of state } \\
\text { programs; } \\
\quad \bullet \quad \text { To direct and organize } \\
\text { the activities of the governing } \\
\text { bodies on the ground and ensure } \\
\text { their interaction with local self- } \\
\text { governing bodies in a state of } \\
\text { war or state of emergency. }\end{array}$ & $\begin{array}{l}\text { • Adapting the } \\
\text { policy objectives of the } \\
\text { Council of Ministers to } \\
\text { local conditions, } \\
\text { coordinating and monitoring } \\
\text { the implementation of tasks } \\
\text { deriving from it; } \\
\qquad \text { Ensuring } \\
\text { coordination of all bodies of } \\
\text { state power and local self- } \\
\text { government, as well as the } \\
\text { management of their } \\
\text { activities in the field of } \\
\text { prevention of threats to life, } \\
\text { health, property, } \\
\text { environment and security of } \\
\text { the state; } \\
\quad \text { The } \\
\quad \text { implementation and } \\
\text { coordination of tasks in the } \\
\text { field of defence and } \\
\text { security, as well as crisis } \\
\text { management. }\end{array}$ & 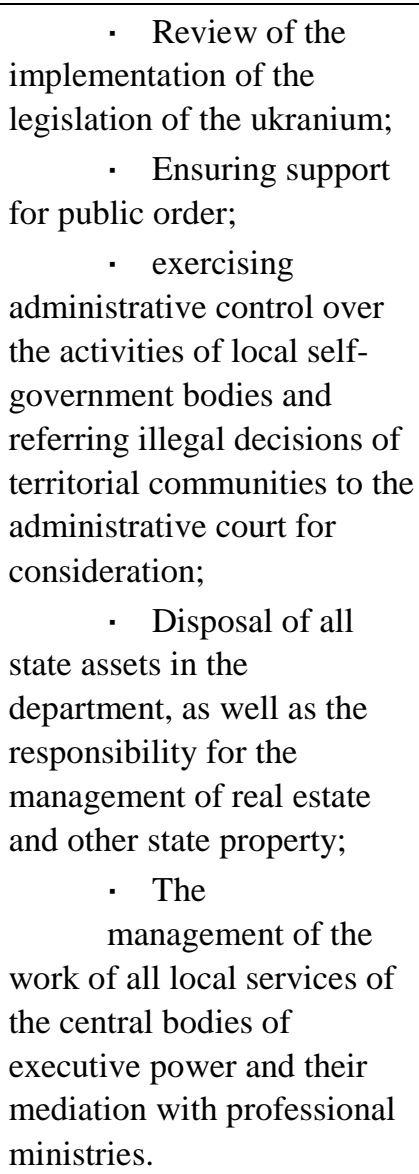 \\
\hline
\end{tabular}




\section{N. Kalakun}

Continuation of Table 1

\begin{tabular}{|c|c|c|c|}
\hline 1 & 2 & 3 & 4 \\
\hline $\begin{array}{l}\text { Authority to } \\
\text { supervise local } \\
\text { self- government } \\
\text { bodies }\end{array}$ & $\begin{array}{l}\text { Cancels the acts of local self- } \\
\text { government on the grounds of } \\
\text { their unconstitutionality; }\end{array}$ & $\begin{array}{l}\text { Within } 7 \text { days, local self- } \\
\text { governance bodies must } \\
\text { submit to the local } \\
\text { government the decision of } \\
\text { the relevant board or council. } \\
\text { If the resolution contradicts } \\
\text { the law, it is invalid in whole } \\
\text { or in part, and the inspection } \\
\text { body shall inform the relevant } \\
\text { local self- government body } \\
\text { within } 30 \text { days from the } \\
\text { receipt of the resolution, } \\
\text { which has the right to cancel } \\
\text { the valid resolution. If within } \\
30 \text { days the decision on the } \\
\text { appropriate act is not taken, it } \\
\text { is considered to be in } \\
\text { compliance with the } \\
\text { legislation. }\end{array}$ & $\begin{array}{l}\text { The councils submit all } \\
\text { decisions to the prefects and } \\
\text { only after the decision has } \\
\text { been reviewed and approved } \\
\text { by them, it is deemed to be } \\
\text { valid. If it is not in } \\
\text { conformity with the law, the } \\
\text { decision on revocation shall } \\
\text { be taken by the court, to } \\
\text { which the prefect may appeal } \\
\text { within } 2 \text { months if there is } \\
\text { any discrepancy. }\end{array}$ \\
\hline $\begin{array}{l}\text { Decision on the } \\
\text { release of } \mathrm{MHI}\end{array}$ & $\begin{array}{l}\text { If local councils adopt an act } \\
\text { violating the Constitution of } \\
\text { Ukraine, territorial integrity and } \\
\text { sovereignty, or endangering } \\
\text { national security, the President } \\
\text { shall suspend the act, suspend } \\
\text { the activity of the council, apply } \\
\text { to the Constitutional Court, and } \\
\text { appoint an hourly commissioner. }\end{array}$ & $\begin{array}{l}\text { In case of gross violations } \\
\text { of the Constitution or laws } \\
\text { of Poland, the parliament } \\
\text { may dismiss the } \\
\text { representative body at the } \\
\text { request of the head of the } \\
\text { government. }\end{array}$ & $\begin{array}{l}\text { If the local government is } \\
\text { unable to ensure proper } \\
\text { management of the } \\
\text { commune, the president can } \\
\text { approve the decree on its } \\
\text { dismissal at a meeting of the } \\
\text { government. }\end{array}$ \\
\hline
\end{tabular}

In Ukraine, the institution of the prefect is a local authority in the system of administrative authorities. A prefect of a region can also be a prefect of a district if his or her territory includes the territory of the regional center. For example, the prefect of Kyiv is also the prefect of Kyiv region. According to the draft law "On the Prefect", the prefect during his/her activity has the following main lines of activity:

1) Supervision of compliance with the Constitution and laws of Ukraine by local selfgovernment bodies and their officials;

2) coordinating the activities of territorial bodies of ministries and other central bodies of executive power, monitoring their compliance with the Constitution and laws;

3) Ensuring implementation of state programs;

4) conjugation and organization of activities of territorial bodies of central authorities and their interaction with local self-government bodies under the legal regime of martial law and state of emergency,

Zone of extraordinary environmental situation, as well as the threat or occurrence of an emergency situation of the appropriate level. [2]

Prefectures in Ukraine have to act on the basis of principles:

- the rule of law;

- in the open;

- legality;

- the single law enforcement;

- the uninterrupted maintenance of the permanent exercise of the judicial power in the districts, regions, Kyiv and Sevastopol, regardless of political processes in the state and beyond its borders;

- of control;

- efektivnosti;

- of political inexpediency. [2] 


\section{Decentralization of power in european countries: theexperience of polish and french...}

After the institution of prefects is introduced, it is envisaged that he will be a civil servant, his term of office at the corresponding level of administrative and territorial unit, can be only 3 years, and further rotation to another level, or even another administrative unit. According to the draft law "On the Prefect" [2], the prefect is appointed to the post and dismissed from it irrespective of the political powers of different political forces, including the presidency of this or that president. However, in my opinion such an approach is not entirely trustworthy. Indeed, if the powers of the prefect include the functions of control and supervision over compliance with the law in making decisions on these or those other areas of activity by local self-government bodies, The political affiliation may lead to political bias and bias in the prefect's activities.

Let's analyze the experience of France and Poland in the process of decentralization reform implementation.

In France the strong hierarchy and centralization of the state power formed the power relations between the levels of power up to 1982 . However, the legislative basis for the formation of a new local level of power with considerably expanded powers was consolidated in the French Constitution of June 23, 1958 [3], which provided that administrative and territorial local authorities The main goal of the Strategy is to ensure that the objectives and tasks of the State are achieved in the most efficient and effective manner, which are essential for ensuring the stable development and activity of the territory, and the implementation of which is most effectively carried out at their level.

However, the implementation at the state level, constitutionally enshrined reform was able to begin only in 1982 .

The legislation stipulated that the committees, departments and regions would become fully supervised electoral bodies - councils. The laws also clearly defined the division of duties and spheres of influence on the respective competencies among the respective branches of power, As well as the redistribution and redistribution of finances and their use in an appropriate manner for the development or financing of those areas of activity that are most needed. They also determined the organizational structure of the regions, regulatory and legal guarantees given to the apparatus and structural divisions of territorial communities, the method of hiring and dismissal of the leadership positions, Ensuring citizen participation in local self-governance and direct control over the publicity and oversight of their activities, as well as the forms and mechanisms of interaction between communities, departments and regions.

On June 7, 1983 and on June 22, 1983 a number of new legislative acts were passed that ushered in a new stage of reform, in the course of which a complete and complex redistribution of duties between the state authorities and local selfgovernment took place for the benefit of the latter. The package of these laws, not without reservation, formed the Administrative Code of France [3], which is the main legislative support for the local self-government of the French communes.

Poland's experience in public administration reform began much later, namely after the restoration of independence and democracy. The current government of Tadeusz Mazowiecki started reforming the system of public administration immediately after its appointment. The reform was to extend not only to local self-government organizations, but also to the system of central bodies of executive power. The decentralization reform was carried out in two stages.

As in France, the reform was carried out by adopting a legislative basis that could constitutionally consolidate this reform. In 1990, the law "On Local Self-Government" [4] was adopted, which stipulated the transfer of the main part of administrative and public powers to the level of local self-governance bodies, i.e. to local municipalities.

The next stage of the reform began with the adoption of the laws "On Provincial SelfGovernment" and "On Province Self-Government" in 1998. [4], which was used to approve at the legislative level the administrative and territorial reform as a result of which the old and new administrative and territorial units such as districts and voivodships were reformed.

However, I must say that the first stage of the reform lasted for 8 years, which can also indicate the unwillingness of the current local government to take over the expanded responsibilities at once. The Ukrainian scenario of 


\section{N. Kalakun}

implementation of the first stage of the reform also required considerable time expenditures in 2014 and even before the 2020 pre-election.

Thus, the adoption of these laws in the Polish Constitution consolidated the basic legislative provisions that defined the status and powers of local self-government bodies and approved the Polish state structure as a decentralized public authority. It is this structure that guarantees the participation of local self- government bodies in the exercise of state power, and attainment of an essential part of the public powers which the local authorities determine at their own discretion in accordance with the needs and under their own responsibility, and have an absolute majority of the powers in their possession.

However, to ensure the proper implementation of the functions delegated by the state and responsibilities of local self-government, the law also establishes the notion of the necessity to form a system of supervisory bodies for the activities of local self-government within their competence. The Head of the Council of Ministers and the governors are responsible for supervising the proper functioning of the self- governing bodies in Poland, and the regional chambers of local councils are responsible for financial security. The relevant administrative oversight and control is also mentioned in the French Constitution, which designates as such an oversight body the prefect, who is the representative of the public authority on the ground.

The French Constitution enshrines the provision that in administrative and territorial units of the republic the representative of the state, who represents each member of the government, is responsible for ensuring national interests, administrative control and compliance with the law [3].

The main supervisory bodies of the State on the ground in Poland and France are the voivods and prefects, respectively.

The competence and principles of the function of the Voivode are set out in the Polish Law on the Voivode and County Administration in Voivodeship, which specifies that the Voivode is the representative of the Council of Ministers in Voivodeship and the supervisor of the activities of local self-government bodies in terms of the rule of law [4].
Since the military commander is a local body of the executive power, the decision on his/her appointment or dismissal is made by the Head of the Council of Ministers upon the submission of the Minister, who has the authority of the public administration.

The Head of the Polish Council of Ministers shall supervise the activities of the troopers, periodically assess the activities and the proper exercise of the powers vested in him/her, and shall be advised by the prefect of his/her activities.

The minister in charge of public administration shall supervise the performance of the duties of the chief executive in accordance with certain eligibility criteria under applicable law, and shall also verify its performance of the respective duties in accordance with the competency and dominance of the leader. The Head of the Council of Ministers shall oversee solely the performance of the chief of staff in accordance with the policy of the Council of Ministers.

As the representative of the Council of Ministers on the ground, the military commander ensures the implementation of a certain list of tasks, in particular

In accordance with the conditions of local self-government, adapts the objectives of the policy of the Council of Ministers, and directly coordinates and monitors the implementation of its tasks, to ensure the sustainable development of the territories;

- Coordinates the interaction of all local and regional authorities that support the activities of the military, and, accordingly, controls the leadership process in the sectors, which provide the necessary conditions for the stable existence of the territory and the people, including civil security, health care, The law enforcement and municipal law enforcement agencies and other important criteria for ensuring public order and other important criteria that are of primary importance in ensuring the functioning of the districts, provinces and municipalities;

- Protecting the defense system of the country and ensuring anti-crisis management, which is enshrined in the relevant legislation.

Similar powers are exercised by the French prefect, who has the capacity of a representative of the State power in the department and is appointed 


\section{Decentralization of power in european countries: theexperience of polish and french...}

by presidential decree, approved at a meeting of the Council of Ministers. At the meeting of the Council of Ministers, the future prefects are appointed and dismissed by the Prime Minister and the Minister of the Interior. The French Prefect represents the delegated responsibilities of each of the ministers, as well as the management of the relevant units of the Public Administration in the department. Its competence includes protection of national interests of the citizens, supervision over the observance of laws, maintenance of public law and order and the right to home control as prescribed by law.

The main duties of the French prefect are:

- The law of the State Administration and individual professional ministers has been enforced;

- Ensuring support for the protection of public order;

- Supervision and control over the activities of the department and its subordinate authorities (local self-government bodies), In particular, for taking relevant decisions by them, a relevant appeal to the administrative court, if they consider such decision to be illegal or such that does not comply with the law;

- Representation of the state authorities in the sphere of ensuring proper consideration of the implementation of all legal acts, which have legal force at the department level, signing important documents on behalf of the state and being responsible for them, as well as acting as the state representative before the judiciary;

- Coordinates the management of state assets in the relevant department, as well as oversees the management of real estate and other property belonging to the state;

- Ensures smooth operation of the structural divisions of the state services of the central bodies of executive power and coordinates the interaction between them and the central ministries.

However, the French prefect has no control over the functions of the peripheral services of the Ministries of Defence, Finance, Education, Justice and the Inspectorate of Labour.

Since the French prefect and the Polish governor are representatives of the government, they are obliged to inform the latter about the current state of affairs in the territories under their control, and, accordingly, carry out the policy of the current government, report it to the local selfgovernment bodies, and ensure their assistance in the implementation of this policy.

The prefect has a twofold task: to represent the government at the local level of executive power and to represent the legitimate interests of the local government vis-à-vis the government in a reciprocal manner. The prefect, however, is a person who has been apoliticized and, above all, a public servant. Therefore, the prefect has the right to be informed and competent in all areas for which he or she is responsible, to assess the activities and decisions of local self-government bodies objectively, taking into account their specificities, while remaining neutral to any provocations from both the governing bodies and the local selfgovernment bodies.

The institution of prefects is primarily intended to ensure supervision over the implementation of legislation by local self-government bodies in the exercise of the powers delegated to them by the state. Accordingly, Polish law stipulated for the establishment of clear regulation of the supervisory powers of local self-government bodies and their dependence on the powers of individual services and municipalities. The same powers that were in the local self-government bodies before their reorganization, enlargement, and granting a wider range of powers are controlled by prefects only for their compliance with the current legislation, by the mechanisms that are clearly defined and predetermined by the legislation.

In turn, control and supervision of those responsibilities that have been delegated by the superior bodies determines the actual situation in the controlled areas of activity, The duties of municipal authorities provide for the implementation of a comprehensive assessment of their performance by such criteria as legality, competitiveness and sustainability of the activities of the relevant authorities.

For example, within 7 days local selfgovernment bodies are obliged to submit to the Polish governor a certain decision of the relevant council and to give the regional division of the District Chamber the decision which is within their competence. If it is inconsistent with the law or 


\section{N. Kalakun}

contrary to it, its inconsistency is stated as invalid in whole or in part, the supervisory body notifies the relevant council, which has taken such a decision not later than 30 days from the date of receipt. Unlike the local self-government authorities in Ukraine, Polish local councils can within 30 days file a complaint to the administrative court to verify the validity and relevance of the decision on the inadmissibility of the act. Within a month the administrative court is obliged to consider the complaint and issue an appropriate decision, but if the non-compliance of such decision of the local administration is not valid, the court may not recognize the invalidity of the decision, but make an explanation that the decision was issued with partial violation of the law.

If within 30 days of the decision by local authorities, the review of municipal authorities, the governor or the Chamber of Accounts for compliance with all criteria and requirements of the law, the decision is not declared inappropriate, it is considered in accordance with current legislation and shall take effect.

The competence of the French prefect also includes reviewing the legality of legal acts, but if the act of local government or any other French municipal authority is unconstitutional, the administrative court is competent to decide on its revocation. If the prefect is suspected of noncompliance of a decision with the law or the Constitution, he or she shall terminate the action and execute the decision before the court's residual review. If the decision in question relates to those that may threaten the integrity and sovereignty of the state, the prefect may suspend not only the execution of the decision, but also the activities of any self- governing body that has issued the act, for a period not exceeding one month. The decision to suspend the activities of a particular court shall be confirmed by a resolution, and the Minister of Internal Affairs shall be notified in writing.

Also the Polish and French legislation contains certain norms of control enforcement, which are applied in very extreme and unprecedented cases. This is the rule on the possibility of dissolving certain bodies of local government if they are in serious breach of the Constitution and laws or if the relevant council is unable to ensure the management of the commune under its control (the highest level of self-government) on the advice of the French prefect. The Polish leader has to inform the Head of the Council of Ministers and the Sejm about the possibility of dismissal of a certain committee in case of a gross violation of the Constitution or laws, and only the latter can take a reasoned decision on the dismissal of the relevant local government body.

Until the new local government bodies are elected and the system of their integral and smooth functioning is established, the governor or the prefect in charge of their duties. No sooner than two months after the dissolution of the previous local government body, elections shall be held and new local authorities shall be elected.

\section{Findings and propositions}

Therefore, after comparing legislative norms that enshrine the activity of local executive authorities of Poland and France, we can conclude that the main norms of their activity and corresponding powers at the local level of local executive authorities, The draft amendments to the Constitution of Ukraine and the draft law "On Prefect" [2] are mostly in line with the European practice of exercising local powers by the representatives of the local executive authorities, The Law on the Procedure for the Procedure.

For example, according to the draft law "On the Prefect" [2], the local government takes away the right to overrule the decision of the prefect on the legality of acts adopted by them, when the Polish communes and the French communes have it.

Experience of decentralization of the system of public administration and executive power in France is the result of evolutionary processes in the country and changes in the administrative administration of Poland in the process of gaining independence are of great importance for Ukraine, They reflect the necessity of reforming the system of administrative authorities at the local level. Having analyzed this experience, we can conclude that the concept of Ukrainian decentralization reform is based on the European mechanisms of reform, with constitutional reform as the primary 
Decentralization of power in european countries: theexperience of polish and french...

goal. This is based on a clear definition of the basic principles of the activity of the executive power on the basis of a clear division and redistribution of powers between the levels of power, as well as ensuring control over their proper implementation, Compliance with the law and their activities within the limits of this legislation to provide public services at the level at which they are most needed and accessible. That is why the introduction of the prefect institution is necessary according to the subsidiarity principle envisaged by the European Charter of Local Self-Government [5]. Also, after analyzing the responsibilities given to the Ukrainian prefect and his foreign colleagues listed in Table 1, we can make a conclusion that these responsibilities have the French prefect and Voivode of Poland are considerably broader and more flexible than those proposed in the Ukrainian version of the reform. However, this difference can have both pluses reduction of privatization and lawlessness of Ukrainian officials, and disadvantages - lack of control, which can lead to federative formations within the boundaries of one state.

Therefore, the adoption of the law on the prefect, which must detail and clearly define the powers of prefects according to the constitution, will determine the further progress and successful completion of the decentralization reform in Ukraine.

\section{References}

1. On Amendments to the Constitution of Ukraine (on decentralization of power): Draft Law of Ukraine of 1 July 2015 No. 2217a. [Electronic resource].-Mode of access: http://w1.cl.rada.gov.ua/pls/zweb2/ webproc4_1?pf3511=55812
2. About Prefects: Draft Law of Ukraine from 16 October 2015. [Electronic resource]. - Access mode: http://www.minregion.gov.ua/wp-content/uploads/ 2016/01/prefekti-16.11..pdf

3. Constitution of France. [Electron resource]. Access mode: http://pravo- izdat.com.ua/imagel data/Files/ 127/1-13.pdf

4. Constitution of Poland. [Electron resource]. Access mode: http://pravo.org.ua/img/books/files/ 1525439592pol_const_new_a5_web.pdf

5. European Charter of Local Self-Government: Ratified by the Law of Ukraine of June 15, 1997 № 452/97-BP. Electronic resource]. - Access mode: http://zakon.rada.gov.ua/laws/show/994_036

6. I. Bezzub, M. Pitzik, O. Sushinskiy. - Introduction of the institution of prefects in Ukraine: good or bad for local self-government [Introduction of the Prefectural Institute in Ukraine: Corridor or Threat to Local Self-Government]. Electronic resource]. - Access mode: http://nbuviap.gov.ual index.php? option $=$ com_content $\&$ view $=$ article $\& i d=2$ 148:vvedennya-institutu-prefektiv-v-ukrajini\&catid= $8 \&$ Itemid $=350$

7. R. Naumenko, V. Rilska. - Prospects for using the European experience in the implementation of the current model of decentralization of power in Ukraine // E-resource]. - Access mode: http://www.dy. nayka.com.ual?op $=1 \& z=902$

8. Experience of decentralization reforms (based on the materials of Mykolayiv National University named after V. O. Sukhomlinskiy, 2016). [Electronic resource]. - Access mode: http://kyiv.fpsu.org.ua /index.php/sotsialnyi-dialoh/uhody-pro-spivpratsiu/240-

9. Unitary state. The Legal Portal. [Electron resource]. Access mode: http://opravovedenii.ru/index.php? option=com_content $\&$ view $=$ article $\& i d=15:$ unitarna derzhava\&catid $=2 \&$ Itemid $=5$ 